\title{
In vitro Antioxidant and Hepatoprotective Activity of Bridelia scandens (Roxb.)Willd.
}

\author{
Preetham Jinadatta ${ }^{1 *}$, Kiran Sundera Raja Rao', Sharath Rajshekarappa ${ }^{2}$, Sujan Ganapathy Pasura Subbaiah ${ }^{3}$, \\ Mruthunjaya Kenganora ${ }^{4}$
}

\section{Preetham Jinadatta ${ }^{*}$, Kiran Sundera Raja Rao', Sharath Rajshekarappa², Sujan Ganapathy Pasura Subbaiah ${ }^{3}$, Mruthunjaya Kenganora ${ }^{4}$}

\section{'Department of Biotechnology, Dayananda Sagar College of Engineering, Kumaraswamy Layout, Bangalore-560078, Karnataka, INDIA. ${ }^{2}$ Department of Biotechnology, M.S. Ramaiah Institute of Technology, MSRIT Post Bangalore 560054, Karnataka, INDIA. \\ ${ }^{3}$ Research and Development Centre, Indusviva International Private Limited, No.7450, Near Navayuga Toll Gate Office, $\mathrm{NH}-4$, Nelamangala, Bangalore -562123, INDIA. \\ ${ }^{4}$ Department of Pharmacognosy, JSS College of Pharmacy, JSS University, Mysuru-570015 Karnataka, INDIA. \\ Correspondence \\ Preetham Jinadatta \\ Research Scholar, Department of Biotechnology Dayananda Sagar College of Engineering, Kumaraswamy Layout, Bangalore -560078, Karnataka, INDIA. \\ Phone no:- +91-9448117536 \\ E-mail: preethamjharsha@gmail.com History \\ - Submission Date: 18-09-2017; \\ - Review completed: 27-10-2017; \\ - Accepted Date: 20-11-2017}

DOI : 10.5530/pj.2017.6s.167

Article Available online http://www.phcogj.com/v9/i6s

Copyright

() 2017 Phcog.Net. This is an openaccess article distributed under the terms of the Creative Commons Attribution 4.0 International license.

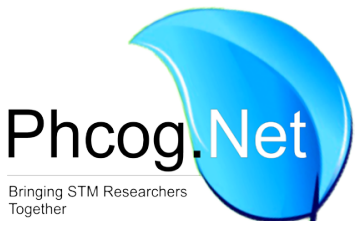

\begin{abstract}
Natural products are emerging out as potent and alternative therapies for many diseases. Today herbs have become the part of mankind, because of its manifold ways in targeting diseased cells with minimal effects on normal cells and tissues. The present research investigated the in vitro antioxidant activity and hepatoprotective of B.scandens leaf. Preliminary phytochemical analysis exhibited the presence of most of the constituent in ethanol extract (BSE). Antioxidant capacity of various extracts of B.scandens was examined. DPPH assay revealed that ethanol extract has a good antioxidant with $\mathrm{IC}_{50}$ value of $31.68 \mu \mathrm{g} / \mathrm{ml}$, whereas standard ascorbic acid with $8.78 \mathrm{\mu g} / \mathrm{ml}$. BSE revealed dose dependent response with increase in concentration for reducing power assay. ORAC assay directly measured the scavenging capacity and BSE (2485 trolox eq/gm) was found to be potent than other extracts. In vitro hepatoprotective activity was performed for BSE using MTT assay in BRL 3A cell line, which revealed nontoxic dose with CTC $_{50}$ value more than $1000 \mu \mathrm{g} / \mathrm{ml}$. At the dose $200 \mu \mathrm{g} / \mathrm{ml}$, BSE and standard silymarin offered cell protection of $57 \%$ and $76 \%$ respectively. Present study concludes that B.scandens leaf extract possess antioxidant potential and protect the liver cells against $\mathrm{CCl}_{4}$ damage. However in vivo studies are being carried out to validate the traditional usage of Bridelia scandens.

Key words: Bridelia scandens, BRL3A, ORAC, MTT, Hepatoprotective.
\end{abstract}

\section{INTRODUCTION}

Medicinal plants are still a potent source of therapeutic agent. These plants and their extracts are being used as natural sources to treat various illnesses. ${ }^{1}$ People of India have remarkable passion for medicinal plants and its use in healing health related issues. India being populated by a substantial number of tribal groups, with enormous knowledge of using wild plants for remedying human complaints. ${ }^{2}$ Today liver disease is one of the serious complaints in the world and to maintain a healthy liver is a decisive aspect for the present population. Despite of remarkable improvements in modern treatment for liver disorders, there is no effectual remedy for restoration of liver functions or regeneration of hepatic cells. So, the herbal remedies are in huge demand for developed and developing country for health issues. Nature has bestowed us with herbs, which extends its use for Protection for liver from being injured or assist in revival of hepatic cells with less or no side effects. ${ }^{3}$

Bridelia scandens belonging to the family Euphorbiaceae, is a perennial herb, native to Southeast Asia, southern China, and the Indian Subcontinent. ${ }^{4}$ It is used in Ayurveda system of medicine as Pashnubeda. ${ }^{5}$ Leaf ${ }^{6,7}$ and stem bark $^{8}$ extracts is used to treat jaundice. Leaf extract is used to cure allergy, ${ }^{9}$ treat oral problems. ${ }^{10}$ Leaf and root extracts are used to treat inflammation, scabies, dermatitis. ${ }^{11}$ Root is also used to cure herpes. ${ }^{12}$ Bark is used to treat cough, fever and asthma, and also possess hypotensive and hypoglycaemic activity. Fruits are edible. Seeds possess hemagglutinating properties ${ }^{7,13,14}$ Decoction of wood of B.scandens administered orally to treat malaria disease. ${ }^{15}$

Herbal based therapies for the liver diseases are used from long time ago and are popular world over. Still, there is no potent and effective drug available to stimulate hepatic cells and help in revival to perform vital functions. Based on the tribal usuage of leaf of Bridelia scandens and medical practitioners to treat jaundice and other ailments, present study has been carried out to investigate antioxidant and antihepatotoxic activity by using in vitro parameters.

\section{MATERIAL AND METHODS}

\section{Plant material and extraction}

Bridelia scandens was collected from Biligiri Rangana hills (BR hills) of Chamarajanagar district, Karnataka, India. Authenticated by Dr. Shiddamallayya N, at National Ayurveda Dietetics Research Institute, 
Department of AYUSH, Govt. of India, Bangalore and was deposited for future references (No: RRCBI-MUS-10121). Leaf material was shade dried, powdered and extracted successively with petroleum ether, chloroform and ethanol using soxhlet apparatus and water extract by refluxing the marc in waterbath. All the extracts of B.scandens were filtered and solvent was evaporated by using rotary evaporator.

\section{Phytochemical analysis}

Different extracts of B.scandens, BSP (B.scandens petroleum ether), BSC (B.scandens chloroform extract), BSE (B.scandens ethanol extract), BSA- (B.scandens aqueous extract) was obtained after extraction. All the extracts were considered for preliminary qualitative phytochemical analysis. Test for carbohydrates, alkaloids, phenols, flavonoids, tannins, terpenes, phytosterols, glycosides, resins were carried out using the standard methods as described. . $^{16,17,18,19,20}$

\section{In vitro Antioxidant activity DPPH radical scavenging assay}

DPPH radical scavenging assay is a discoloration assay, upon reaction with hydrogen donor changes purple to yellow colour. It is evaluated by the addition of the antioxidant to a DPPH and was performed as described by cuendet et al $1997^{21}$ taking ascorbic acid as standard. $4.0 \mathrm{ml}$ $(0.2 \mathrm{mg})$ of DPPH solution in methanol was added to $1 \mathrm{ml}$ of various concentrations $(7.62-250 \mu \mathrm{g})$ of plant extracts. After 30 mins of incubation period at room temperature the absorbance was read at $517 \mathrm{~nm}$.

\section{Reducing power assay}

The capacity of the plant extracts to reduce iron III was measured by using different concentrations $(50-300 \mu \mathrm{g} / \mathrm{ml})$ and standard ascorbic acid. Add $2.5 \mathrm{ml}$ of $0.2 \mathrm{M}$ phosphate buffer $\mathrm{pH} 6.6$ and $2.5 \mathrm{ml}$ of $1 \%$ aqueous potassium hexacyanoferrate solution. Incubate for $30 \mathrm{mins}$ at $50^{\circ} \mathrm{C}$, add $2.5 \mathrm{ml}$ of $10 \%$ TCA (trichloroacetic acid) and centrifuge at $3000 \mathrm{rpm}$ for 10 mins.Collect $2.5 \mathrm{ml}$ of supernatant and mix it with $2.5 \mathrm{ml}$ of water and $0.5 \mathrm{ml}$ of $0.1 \%$ aqueous $\mathrm{FeCl}_{3}$. The amount of iron ferricyanide complex could be determined by measuring the formation of perl's Prussian blue at $700 \mathrm{~nm} .{ }^{22} \mathrm{~A}$ higher absorbance indicates higher reducing power.

\section{ORAC assay}

ORAC (Oxygen Radical Absorbing Capacity) assay was performed to scavenge the peroxyl radical as well as to estimate the total antioxidant capacity of the test drug. Phosphate buffer ( $\mathrm{pH} 7.4$ ) was used to prepare the plant extracts and using sodium fluorescein as a probe in Synergy ${ }^{\mathrm{m}}$ HT fluorescence multiplate reader. Plant extracts solution and/or $25 \mu \mathrm{l}$ of Trolox of $1 \mathrm{mM}$ were allotted in 96-well micro titre plate. $150 \mu \mathrm{l}$ of the fluorescein $(4 \mu \mathrm{M})$ solution added to each well, mixed thoroughly, incubated at $37^{\circ} \mathrm{C}$ for 30 mins Synergy ${ }^{\mathrm{nm}} \mathrm{HT}$ multi-detection microplate reader. Add $25 \mu \mathrm{l}$ of AAPH (153 mM, 2.2'-Azobis (2-methylpropionamidine dihydrochloride) using dispenser and mixed well. Fluorescence of standard and plants extracts were monitored continuously every minute for 1 hour using the reader plate, controlled by using $\mathrm{KC}^{\text {mix }}$ software version $3.4 .^{23}$

\section{Hepatoprotective activity on BRL3A cell line 24,25,26}

\section{Cell lines and Culture medium}

In the present study BRL3A(Buffalo Rat liver cell line) cell line was used to assess the hepatoprotective function of potent extract (BSE). BRL3A was obtained from National Centre for Cell Sciences (NCCS), Pune, India. It was cultured in DMEM (Dulbecco's modified eagles medium), supplemented with $10 \%$ inactivated fetal Bovine serum(FBS),100IU/ml of pencillin, $100 \mu \mathrm{g} / \mathrm{ml}$ of streptomycin and $5 \mu \mathrm{g} / \mathrm{ml}$ amphotericin in an humidified atmosphere of $5 \% \mathrm{CO}_{2}$ at $37^{\circ} \mathrm{C}$ until confluent. Later the cells were dissociated with TPVG solution containing $0.2 \%$ trypsin, $0.02 \%$
EDTA, $0.05 \%$ glucose in PBS. Stock cultures were grown in $25 \mathrm{~cm}^{2} \mathrm{cul}-$ ture flasks and study was carried out in 96 microtitre plates.

\section{Preparation of Test Solutions}

Stock solution of $10 \mathrm{mg} / \mathrm{ml}$ concentration of plant extract was prepared by dissolving sample in DMSO and then volume was made upto with DMEM, supplemented with $2 \%$ inactivated FBS. Stock was serially diluted to get lower concentrations.

\section{Evaluation of cell viability by MTT Assay}

MTT assay was carried out for ethanol extract of B.scandens to assess its nontoxic doses. A monolayer cell culture was trypnised and count was accustomed to $1.0 \times 10^{5}$ cells $/ \mathrm{ml}$ using DMEM containing $10 \% \mathrm{FBS}$. Approximately 10,000 cells $(0.1 \mathrm{ml}$ diluted suspension) were added to each 96 well microtitre plate. After $24 \mathrm{hrs}$, supernatant was flicked off to form a partial monolayer of cells and was washed with medium. $100 \mu \mathrm{l}$ of different test concentrations $(62.5-1000 \mu \mathrm{g} / \mathrm{ml})$ was added to each well and then incubated at $37^{\circ} \mathrm{C}$ for 3 days in $5 \% \mathrm{CO}_{2}$ atmosphere. Microscopic examination and observations were noted in $24 \mathrm{hrs}$ time interval. After $72 \mathrm{hrs}$, test samples were disposed and MTT in PBS (50 $\mu \mathrm{l})$ was added to each well. Again incubated at $37^{\circ} \mathrm{C}$ for 3 days in $5 \% \mathrm{CO}_{2}$ atmosphere, supernatant was removed, $100 \mu \mathrm{l}$ of propanol was added and the plates were gently shaken to solubilize the formed formazan. Microplate reader at a wavelength of $540 \mathrm{~nm}$ was used to read the absorbance and percentage of growth inhibition was calculated using the formula. $\mathrm{CTC}_{50}$, concentration of test drug needed to inhibit cell growth by $50 \%$ is generated from the dose-response curves for test samples.

$\%$ Growth Inhibition $=100-$ Mean OD of control group $/$ Mean OD of individual test group $\times 100$

\section{Determination of Hepatoprotective activity}

Non-toxic or safe concentration chosen was ethanol extract for B. scandens to determine antihepatotoxic property. The protocol was followed as mentioned for MTT assay. To nontoxic test concentration (50 $\mu \mathrm{l})$, add $50 \mu \mathrm{l}$ of DMEM with nontoxic concentration $\left(1 \% \mathrm{CCl}_{4}\right)$ of toxicant were added. Micro plate reader was used to measure the absorbance at a wavelength of $540 \mathrm{~nm}$ and percentage cell viability was determined. Based on which the Percentage protection offered by plant extract and standard silymarin was calculated over the DMSO control.

$\%$ Cell protection $=$ Mean O.D of individual test group $/$ Mean O.D of control group $\times 100$

\section{RESULTS}

Leaf of $B$. scandens subjected to successive extraction resulted with four extracts, BSP (B.scandens petroleum ether), BSC (B.scandens chloroform extract), BSE (B.scandens ethanol extract), BSA- B.scandens aqueous extract. Preliminary phytoconstituents present in different extracts of leaf of B.scandens were revealed in Table 1. It showed that most of constituents like, carbohydrates, phenols, flavonoids, tannins, phytosterol and terpenes in ethanol extract (BSE).

\section{Antioxidant assays}

Antioxidant activity of different extracts of B.scandens was measured by DPPH scavenging assay, reducing power and ORAC assay. In DPPH assay,BSE showed potent scavenging activity with $\mathrm{IC}_{50}$ value of $31.68 \pm 0.40$ $\mu \mathrm{g} / \mathrm{ml}$, whereas standard ascorbic acid with $8.78 \mu \mathrm{g} / \mathrm{ml}$. Comparitively, less activity was found in BSC, negligible in BSP and nil scavenging activity in BSA (Graph 1). Reducing power of different extracts of B. scandens was measured (Graph 2). BSE showed high reducing power with increasing in concentration. BSC extract showed moderate activity and BSP with very less activity followed by BSA.ORAC assay was performed for all the four extracts of B.scandens and it showed a good oxygen radical absorbing 
capacity for BSE (2485 trolox eq/gm) and ascorbic acid (3562 trolox eq/gm) followed BSC (Graph.3). BSP and BSA didn't show any activity.

Since ethanol extract (BSE) proved to be a good antioxidant, it was further considered to test its hepatoprotective ability on BRL3A cell line.

\section{Hepatoprotective activity}

Hepatoprotective activity of BSE was examined on BRL3A cell line. BSE exhibited $\mathrm{CTC}_{50}$ of more than $1000 \mu \mathrm{g} / \mathrm{ml}$ (Table 2). Nontoxic dose of BSE tested for its hepatoprotective activity on BRL 3A cell line intoxicated with $\mathrm{CCl}_{4}$ showed that $57 \%$ shielding effect $(200 \mu \mathrm{g} / \mathrm{ml})$. whereas standard silymarin at $200 \mu \mathrm{g} / \mathrm{ml}$ exhibited $76.3 \%$ (Table 3).

\section{DISCUSSION}

In the present investigation phytoconsituents of various extracts of B.scandens was examined. In vitro antioxidant potential, cytotoxicity and hepatoprotective activity of B.scandens was evaluated. The chemicals and drugs used in the routine life damage liver cells by inducing lipid peroxidation and altering the cellular redox state piloting to oxidative stress/ damage in the system. Reactive oxygen species (ROS) produced due to this stress initiate and regulate the progression of liver diseases. The inequity between the ROS production and antioxidant defense mechanisms leads to oxidative stress. This impacts the transcription of various biochemical mediators, which can modulate other affairs in the system like cholestasis, apoptosis, fibrosis, and regeneration. This leads to different types of liver diseases. ${ }^{27,28}$

These medicinal plants are always beneficial for mankind by resolving the health issues and various studies has been conducted on traditional medicine to develop new drug for antioxidant and hepatoprotective activity. $^{29}$

Ethanol extract of B.scandens has phytoconstituents like phenols flavonoids, tannins, alkaloids. In the present findings, in vitro antioxidant activity of different extracts revealed that, compare to all the extracts used, ethanol extract is having a good scavenging and reducing capacity. ORAC assay analyse scavenging of peroxyl radical. This also examines the antioxidant capacity of all the antioxidants present in the test. ${ }^{23,30}$ ORAC results revealed that ethanol extract of B.scandens as potent antioxidant than other extracts, indicating the direct measure of antioxidant ability of the extract. As the value of ORAC increases, antioxidant competence also increases and vice versa. ${ }^{31,32}$ Antioxidants from natural products detoxify the toxins, scavenging of free radicals, removes excess

\section{Table 1: Phytochemical analysis of different extract of B.scandens}

\begin{tabular}{cccccc}
\hline & Tests & BSP & BSC & BSE & BSA \\
\hline 1 & Alkaloids & - & - & + & - \\
2 & Carbohydrates & - & + & + & + \\
3 & Flavonoids & - & + & + & - \\
4 & Phenols & - & + & + & + \\
5 & Glycosides & - & - & + & + \\
6 & Saponins & - & - & - & - \\
7 & Phytosterols & + & + & + & - \\
8 & Resins & + & - & - & - \\
9 & Tannins & - & - & + & - \\
10 & Terpenes & - & - & + & - \\
11 & Proteins & - & - & - & - \\
\hline
\end{tabular}

+ indicates Present, - indicates not determined

BSP (B.scandens petroleum ether extract), BSC (B.scandens chloroform extract), BSE (B.scandens ethanol extract), BSA-B.scandens aqueous extract.
Graphs: Antioxidant activity of B.scandens
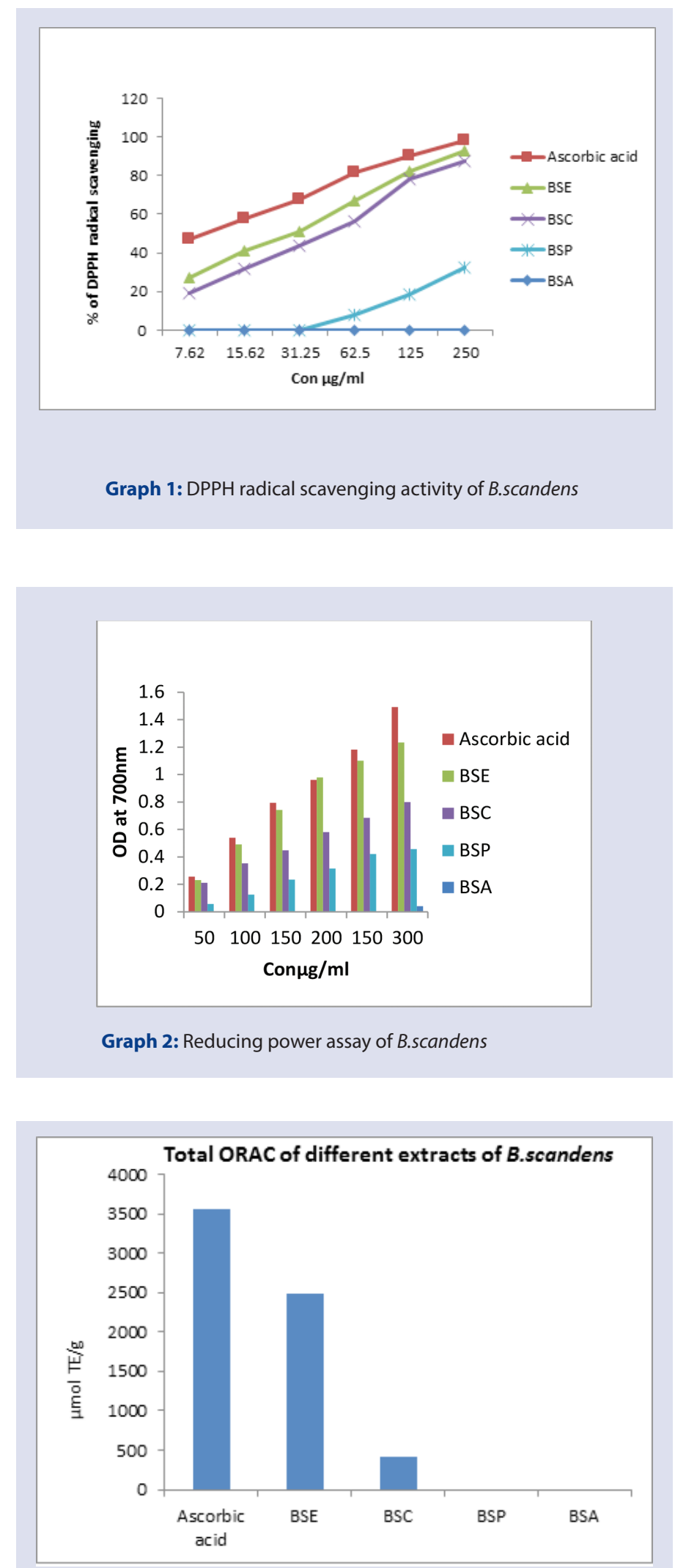

Graph 3: ORAC assay of B.scandens

BSP (B.scandens petroleum ether), BSC (B.scandens chloroform extract), BSE (B.scandens ethanol extract), BSA- (B.scandens aqueous extract). 
Table 2: Cytotoxic property of ethanol extract of B.scandens on BRL3A cell line by MTT assay

\begin{tabular}{cc}
\hline Con $\mu \mathrm{g} / \mathrm{ml}$ & BSE \\
\hline 62.5 & $4.8 \pm 1.47$ \\
125 & $11.1 \pm 0.5$ \\
250 & $16.9 \pm 0.5$ \\
500 & $29.7 \pm 2.3$ \\
1000 & $45.3 \pm 1.1$ \\
$\mathrm{CTC}_{50}(\mu \mathrm{g} / \mathrm{ml})$ & $>1000$ \\
\hline
\end{tabular}

BSE- Bridelia scandens ethanol extract

Table 3: Hepatoprotective study of BSE on BRL3A cell line

\begin{tabular}{ccc}
\hline Test Drug & con $\mu \mathrm{g} / \mathrm{ml}$ & $\%$ Viability \\
\hline Normal cells & - & 100 \\
DMSO & $0.25 \%$ & $98 \pm 0.4$ \\
$\mathbf{C C l}_{4}$ & $1 \%$ & $20.5 \pm 0.5$ \\
Silymarin+ CCl & 200 & $76.3 \pm 0.34$ \\
BSE $+\mathbf{C C l}_{4}$ & 200 & $57 \pm 1.8^{\mathrm{a}, \mathrm{b}}$ \\
BSE+ $\mathbf{C C l}_{4}$ & 100 & $38.6 \pm 1.9^{\mathrm{b}}$ \\
BSE $+\mathbf{C C l}_{4}$ & 50 & $10.3 \pm 2.3^{\mathrm{b}}$ \\
\hline
\end{tabular}

Values are expressed as mean \pm S.E.M; $\mathrm{n}=3$

aSignificance level : $\mathrm{P}<0.05$, compared to DMSO cells

bSignificance Level : $\mathrm{P}<0.05$, compared to Toxicant treated cells

BSE- B.scandens ethanol extract

ROS and anti-lipid peroxidation. ${ }^{33}$ Antioxidant activity of BSE proves that leaf of B.scandens can be used to treat liver disease.

The cell line testing for hepatoprotective activity is a primary level screening, used to investigate medicinal plants. In vitro cytotoxicity and hepatoprotective activity in BRL3A cell line (functions as rat liver cells) was carried out for BSE. MTT, tetrazolium dye is used widely to assess the cell viability and also used to determine nontoxic dose for BSE and found to be above $1000 \mu \mathrm{g} / \mathrm{ml} . \mathrm{CCl}_{4}$ induced hepatotoxicity is a widely used and accepted model to test protective role of the drug because of variation associated with $\mathrm{CCl}_{4}$ - induced liver injury is similar to that of acute viral hepatitis. ${ }^{31,32,33} \mathrm{CCl}_{4}$ is activated by cytochrome $\mathrm{P}_{450}$ dependent monooxygenases to form trichloromethyl radical and trichloromethyl peroxyl free radical. These free radicals lead to severe liver damage. B.scandens tells about its traditional usage to cure liver disease, thus BSE at $200 \mu \mathrm{g} / \mathrm{ml}$ have tried to protect the liver cells from $\mathrm{CCl}_{4}$ damage. This may be due to the antioxidant potency of the BSE and its phytoconsituents.

\section{CONCLUSION}

Medicinal plants are always beneficial for mankind by resolving the health issues. Leaf of B.scandens used traditionally to cure liver disease like jaundice proved to be efficient in shielding the liver cells by its strong antioxidant potential and protecting the normal cells. Detailed in vivo studies on liver protection activity are in progress to support the data obtained.

\section{ACKNOWLEDGEMENT}

Authors are thankful to Dayananda Sagar Insitutions, Bangalore, for providing facilities to carry out the present work.

\section{CONFLICT OF INTEREST}

The authors declare no conflict of interest.

\section{ABBREVIATION USED}

MTT: 3-(4, 5-dimethyl thiazol-2-yl)-5-diphenyl tetrazolium bromide; FBS: Fetal Bovine serum; PBS: Phosphate Buffered Saline; DMEM: Dulbecco's Modified Eagle's Medium; DMSO: Dimethyl Sulfoxide; PBS: Phosphate Buffered Saline; BRL3A: Buffalo Rat liver; TPVG: Trypsin Phosphate Versene Glucose; 0.2\% trypsin, 0.02\% EDTA, 0.05\% glucose; DPPH: 2,2-diphenyl-1-picrylhydrazyl.

\section{REFERENCES}

1. Mahinder R, Deepak Acharyah, José Luis Rios. Ethanomedicinal plants. Revitalization of traditional knowledge of herbs. Science publishers, p.2011.

2. Sayed NZ. Medicinal Plants: A Holistic Approaches, New India publishing Agency, New Delhi. P. 2011:22-3

3. Tarashankar M, Surajit M, Nilanjan P, Durgesh RK, Subarna G. A review on hepatic diseases and development of herbal drugs for the treatment of liver complications. World J Pharm Res. 2015;4(6):677-91.

4. Senthil KD, Kottai MA, Satheesh KD, Manavalan R. In vitro antioxidant potential of various extracts of whole plant of Bridelia scandens (Roxb) wild. Der Pharma Chemica. 2010;2:195-201.

5. Madhavan V, Priyanka GK, Gurudeva MR, Yoganarasimhan SN. Pharmacognostical studies on the root of Nothosaerva brachiata Wt. - A botanical source of the Ayurvedic drug, Pashanabheda. Indian j. tradit. knowl. 2010;9(4):629-34.

6. Ramashankar, Rawat MS, Deb S, Sharma BK. Jaundice and its traditional cure in Arunachal Pradesh. J. pharm. sci. innov. 2012;1(3):93-7.

7. Sankaranarayanan AS: Folk-lore medicines for jaundice from Coimbatore and Palghat districts of Tamilnadu and Kerala, India. Anc Sci Life. 1988;7(3-4):175-9.

8. Lalitha.RS, Kalpana DV, Tresina SP, Maruthupandian A Mohan VR. Ethanomedicinal plants used by Kanikkars of Agasthiarmalai Biosphere Reserve. Western Ghats. J. ecobiotechnol. 2011;3(7):16-25.

9. Tuhin K, Reatul K, Sharmin RC, Rebecca B. Ethanomedical Studies of Chakma Communities of Chittagong Hill Tracts. Bangladesh. Bangladesh Pharm J.2012;15(1):59-67.

10. Maji J, Bhagya B, Manjula S. Ethan medicinal herbs used in oral health and hygiene in coastal dakshina kannada. J Oral Health Comm Dent. 2011;5(3):119-23.

11. Shahadat H, Prozzal R, Syeda S, Sadia MM, Mirza NM, Sharmin J et al. Ethanomedicinal knowledge among the Tonchongya tribal community of Roangchaari Upazila of Bandarban district, Bangladesh. Am.-Eurasian J. Sustain. Agric. 2012:6(4):349-59

12. Bhandary MJ, Chandrashekar KR. Herbal therapy for herpes in the ethno- medicine of coastal Karnataka. Ind J trad know. 2011;10;528-32.

13. Narayan D, Praja pati, Kumar U. Agro's dictionary of medicinal Plants. Agrobios publication; p. 23:2003

14. Yoganarasimma SN. Medicinal Plants of India. Karnataka. vol. 1. Interline publishers. 1996

15. Oratai N, Patcharin S, Kornkanok Y, Narumon S. A survey of medicinal plants in mangrove and beach forests from sating Phra Peninsula, Songkhla Province Thailand. J. Med. Plants Res. 2012;6(12):2421-37.

16. Eshwarappa RS, Iyer S, Subaramaihha SR, Richard SA, Dhananjaya BL. Antioxidant activities of Ficus glomerata (moraceae) leaf gall extracts. Pharmacognosy Res. 2015;7(1):114-20.

17. Harborne JJ. Phytochemical Methods: A Guide to Modern Techniques of Plant Analysis. 2nd ed. New York: Chapman and Hall.1984. p.85.

18. Trease GE, Evans WC. Pharmacognosy. 13th ed. Delhi: ELBS Publication.1989. p. 171.

19. Kokate CK, Purohit AP, Gokhale SB. Pharmacognosy. 23rd ed. Pune: Nirali Prakashan; 1998. p.106-14.

20. Khandelwal KR. Practical Pharmacognosy: Techniques and Experiments.13th ed.. Pune: Nirali Prakashan. 2005. p.149-56.

21. Cuendet M, Hostettmann K, Potterat O. Iridoid glucosides with free radical scavenging properties from Fragrea blumei. Helv Chim Acta. 1997;80(4):1144-51.

22. Sujan Ganapathy PS, Ramachandra YL, Padmalatha Rai S. In vitro antioxidant activity of Holarrhena antidysenterica Wall. methanolic leaf extract. J Basic Clin Pharm. 2011;2(4):175-8.

23. Cao G, Alessio HM, Cutler RG. Oxygen-radical absorbance capacity assay for antioxidants. Free Radic Biol Med. 1993;14(3):303-11.

24. Pavan KB, Ashok G, Mohammed I, Seetaram K, Ramchandra NM, Maradam S. In vitro Cytotoxicity of caralluma species by MTT and Trypan blue dye exclusion. Asian J Pharm Clin Res. 2014;7(2):17-9. 
25. Sadhana S, Yogita B, Sanjay G, Harpreet K, Roopali R. Hepatoprotective effects of aqueous leaf extract and crude isolates of Murraya koenigii against in vitro ethanol-induced hepatotoxicity model. Exp Toxicol Pathol. 2011;63(6):587-91.

26. Alla R, Kuppart LJ, Manikani KL. Protective effect of Paracalyx scariosa (RoxB). Ali against ethanol induced hepatic toxicity in BRL3A Cell lines. Int Res J Pharm. 2014;5(6)495-501.

27. Parola M, Robino G. Oxidative stress- related molecules and liver fibrosis. J Hepatol .2001;35(2):297-306.

28. Morisco F, Vitaglione P, Amoruso D, Russo B, Folgiano V, Caporaso N. Foods and liver health. Mol. aspects Med. 2008;29(1):144-50.

29. Yong SG, Qing H. Plants Consumption and Liver Health. Evid. Based Complement. Alternat. Med.2015, Article ID 824185.

30. DeLange RJ, Glazer AN. Phycoerythrin fluorescence-based assay for peroxy radicals: a screen for biologically relevant protective agents. Analyt Biochem 1989; 177(2):300-6.

31. Ames BN, Shigenaga MK, Hagen TM. Oxidants, antioxidants, and the degenerative diseases of aging. Proc Natl Acad Sci USA. 1993;90(17):7915-22.

32. Huang $D$, Ou B, Prior RL. The chemistry behind antioxidant capacity assays. Journal of agricultural and food chemistry. 2005;53(6):1841-56.

33. Clawson GA. Mechanisms of carbon tetrachloride hepatotoxicity. Pathol and Immunopathol Res. 1989;8:104-12.

34. Rubinstein D. Epinephrine release and liver glycogen levels after carbon tetrachloride administration. Am J Physiol. 1962;203(6):1033-7.

35. Suhail M, Suhail S, Gupta BK, Bharat V. Malondialdehyde and antioxidant enzymes in maternal and cord blood and their correlation in normotensive and preclampatic women. J Clin Med Res. 2009;1(3):150-7.

\section{GRAPHICAL ABSTRACT}

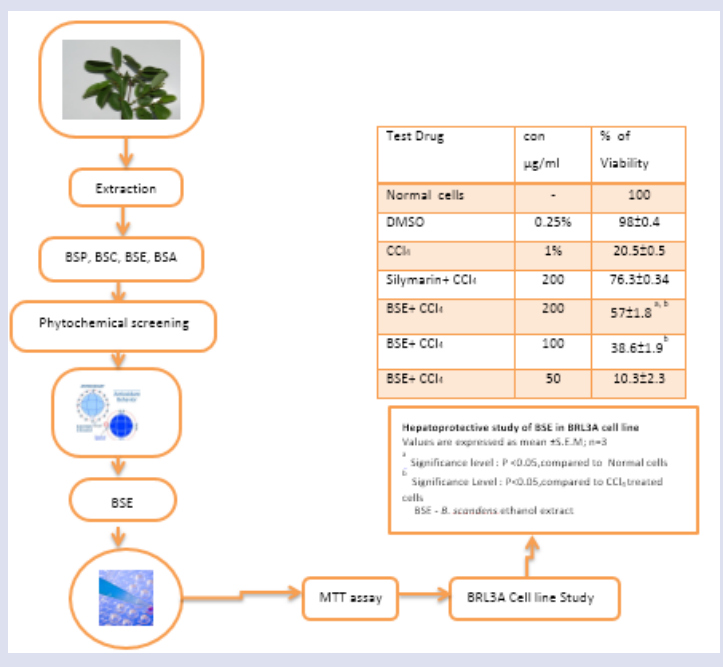

\section{SUMMARY}

- The present investigation on leaf of B.scandens shows its potential as antioxidant and hepatoprotective. Phenols and flavonoids of the plant, as a secondary metabolite serve as a good antioxidant and hepatoprotective agent. Ethanol extract with its phytoconsituents may be responsible for the present activity. It proves to be less toxic on BRL3A cell line, which was revealed by its protective effect against $\mathrm{CCl}_{4}$ toxicity. To expand, In vivo hepatoprotective studies for the ethanol extracts B.scandens being carried out to assess its antihepatotoxic function.

Cite this article: Jinadatta P, Rao KSR, Rajshekarappa S, Subbaiah SGP, Kenganora M. In vitro Antioxidant and Hepatoprotective Activity of Bridelia scandens (Roxb.)Willd. Pharmacog J. 2017;9(6)Suppl:s117-s21. 